How to Cite

Asmawan, G. P. (2019). Is good craft matter increasing ingka quality?. International Journal of Chemical \& Material

Sciences, 2(1), 18-23. https://doi.org/10.31295/ijcms.v2n1.84

\title{
Is Good Craft Matter Increasing Ingka Quality?
}

\author{
Gede Pena Asmawan \\ STIKOM Bali, Denpasar, Indonesia \\ Email: gd.pena.asmawan@gmail.com
}

\begin{abstract}
The purpose of this paper to describe the material on such crafts ingka ingka definition, types ingka, advantages and disadvantages ingka usage, application usage ingka, and the last goal of the use ingka. In addition, I also have a very large goal is to introduce this ingka craft to the crowd that grew ingka users and that child domestic work do not lose competitiveness with foreign products so that local entrepreneurs to develop business in the world market. From my explanation I can conclude that the craft ingka his function was not inferior to foreign products may ingka is superior in its application because it can be used in all activities and more practical in use.
\end{abstract}

Keywords---application, domestic, entrepreneur, inferior, ingka.

\section{Introduction}

The term ingka is creativity that made by someone somewhere who take advantage of the surrounding material so that the material with their idea and have it be the selling price and the value of art. Crafts ingka is an innovation that is full (Ball, 1990; Benedict et al., 2012; Craft et al., 1988). The ideas and serves its purpose very big influence in the present era. Ingka no one knows who first made but ingka from the beginning until now existing in the community despite the way and the results of each area is different.

Ingka has so many benefits that are biased in use by consumers because ingka it is a product that has many benefits in every activity of society everyday like ingka widely used for ritual paraphernalia such as weddings, religious ceremonies, to which many now that the bias we encounter is ingka widely used by food vendors wherever it ingka used to facilitate food and ingka chosen for it because ingka more practical use without having to wash after use like plates, because the principle of a trader and the buyer is wanted practical, fast, clean so between traders and buyers no problems and win-win (Durant et al., 2010; Eichholz et al., 1967; Esposti et al., 2017).

I discussed the matter about handicrafts ingka this so that the craft ingka biased develop better in comparing now so ingka could compete in the world especially now that Indonesia has joined MEA then anything can happen as long as there are businesses, craft ingka someday might be able to change the use of a plate or the like in this world. The material I will discuss it further as to what ingka craft, craft ingka types, advantages and disadvantages of the use of ingka compared to other products, application usage, and more recently ingka what the main purpose of the appearance of this ingka craft

\section{Discussion}

\section{Definition ingka}

The term ingka is creativity that made by someone somewhere who take advantage of the surrounding material so that the material with their idea and have it be the selling price and the value of art. Crafts ingka is an innovation that is full of ideas and serves its purpose very big influence in the present era. Ingka no one knows who first made but ingka from the beginning until now existing in the community despite the way and the results of each area is different but the point ingka that have the same in any given area, and it was the main attraction craftsmen in each 
area to always put out his ideas in order to work a dream of every consumer and in order not to lose competitiveness because the model never changes.

\section{Types of craft ingka}

Each region and the results someone must produce works of art vary, although of the same material but each craftsman must have certain ideas to make work more attractive to consumers. Starting from the moment that a lot of the types of existing ingka like in my area have a name ingka Ajengan, ingka bowl, ingka tray, oval ingka and many others. But every blood may have ingka same type but different in name only. In each model ingka it may only be distinguished from the shape and size alone example like ingka oval size relatively similar to the others but shape oblong or oval (Hollinshead, 2004; Nordmann, 2014; O Craft et al., 2011), in addition ingka round nare same shape but its size is relatively larger than the other ingka. For the area, I have a physical form like this

a. ingka oval Ingka have a form like this ingka ingka usually not round but oval (oval). The average size usual for diameter $30-50 \mathrm{~cm}$.

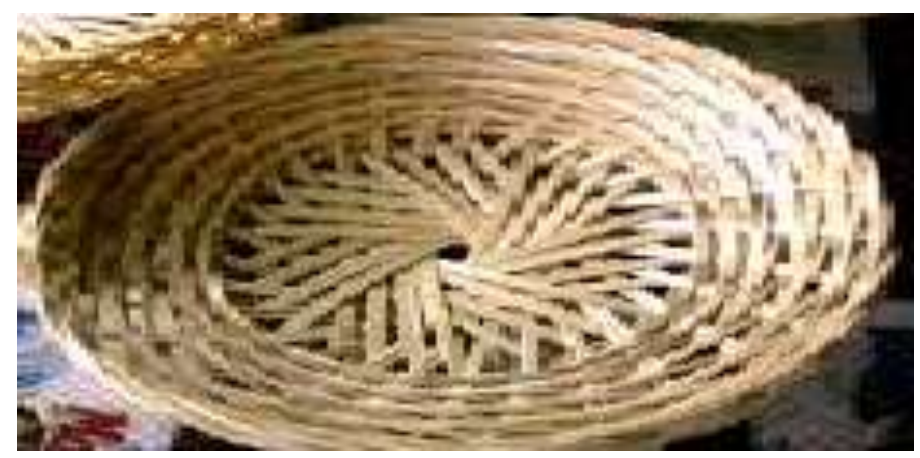

b. ingka eat

This ingka shape exactly once with the dishes that we often use daily from the shape and size. The Average size is often made that a diameter of $28-35 \mathrm{~cm}$.

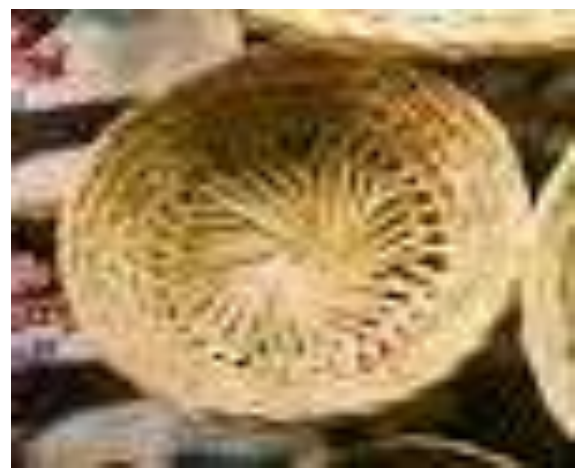

c. ingka Ajengan

Ingka this one is rather different in size that is smaller than the others but ingka ingka resembles a previous meal. The average size of the usual made-diameter $18-25 \mathrm{~cm}$. 


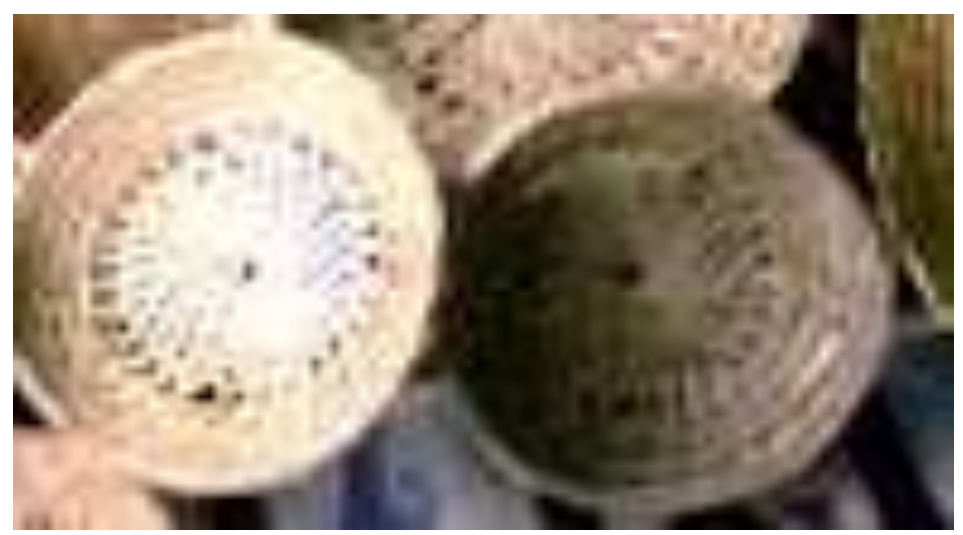

d. ingka bokor

This ingka has a different shape from that we discussed earlier is shaped like a bowl that we usually encounter days. Average size commonly made is $25-40 \mathrm{~cm}$ in diameter.

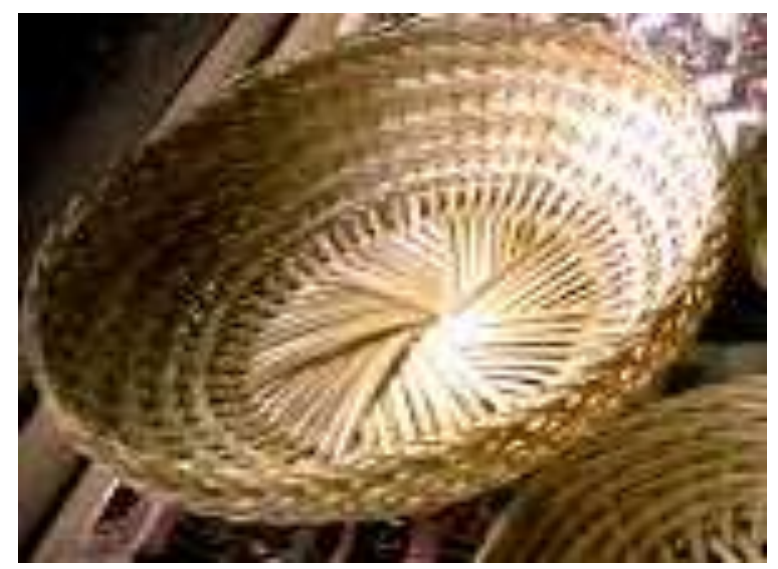

e. Ingka jaje (cake)

Ingka has a size as ingka Ajengan but shapes like ingka bowl. The average size commonly made is between $18-25 \mathrm{~cm}$.

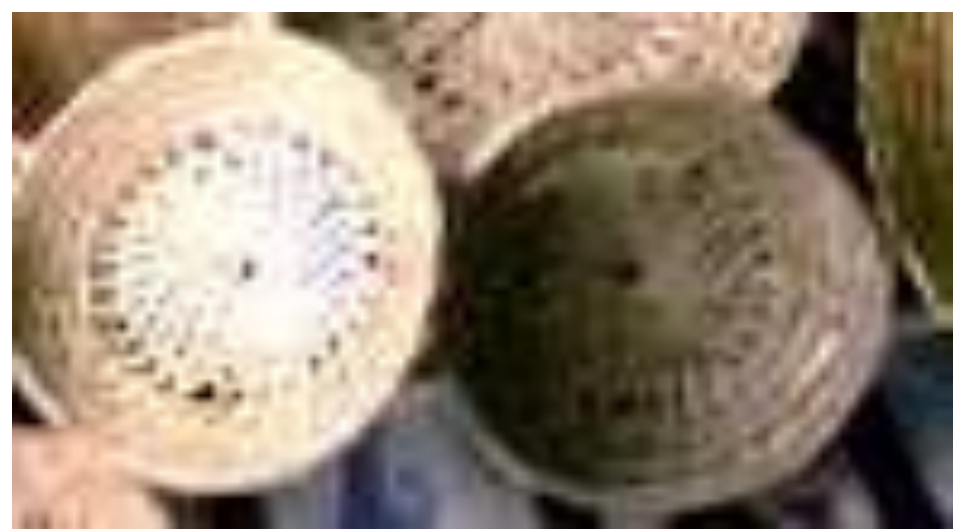

f. ingka nare

Ingka has the most different forms with ingka we discussed previously that the largest size. Average size commonly made is between $40-60 \mathrm{~cm}$. 


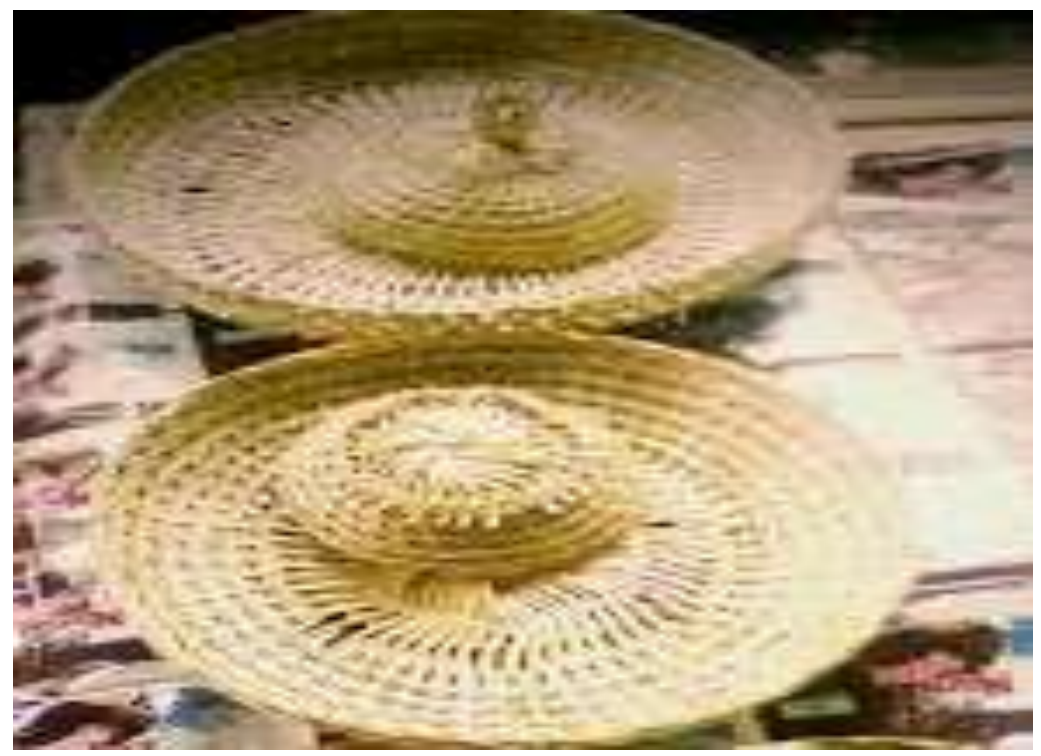

g. ingka tray

Ingka have a shape like a tray that is ingka with longer legs than customarily, ingka usual form in which such ingka create oval, eat, bowl. The average size commonly made is $30-50 \mathrm{~cm}$.

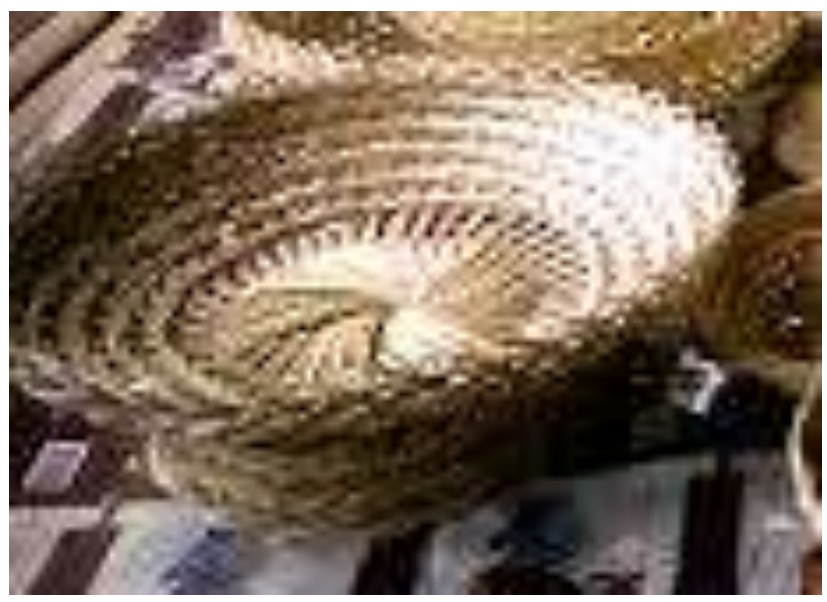

h. Accessories ingka/saab

Saab is complementary accessories from ingka which serves as a cover ingka the average size of which is made is dependent on ingka were made but saab smaller size of about $5 \mathrm{~cm}$ of the large ingka.

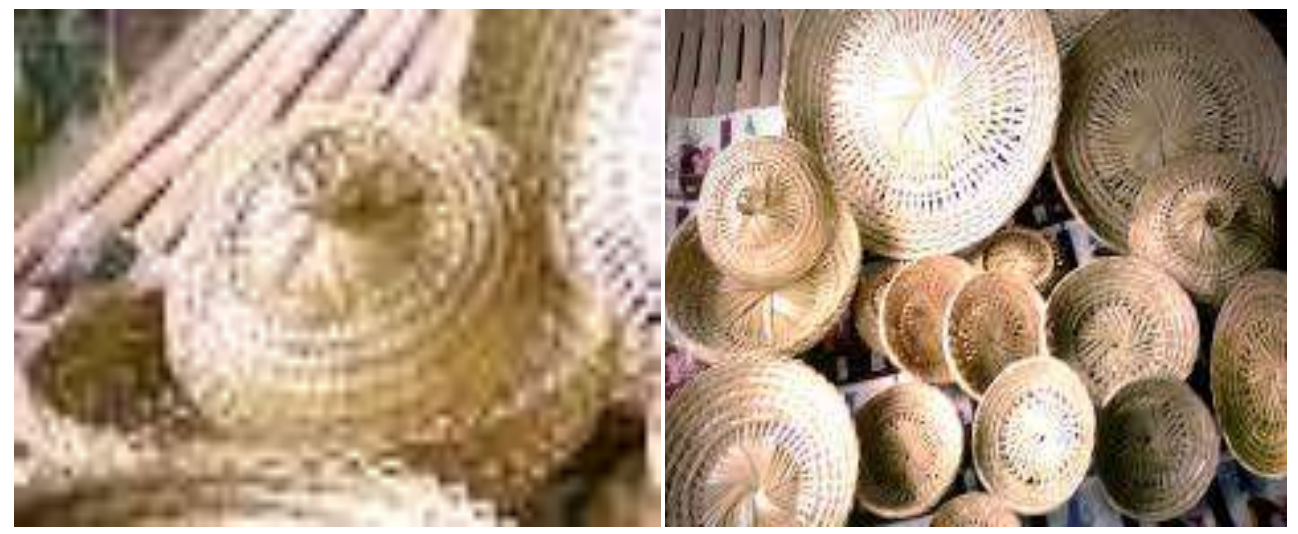




\section{Advantages and disadvantages}

Of the many users ingka now there may be some people who already give their opinions about the current ingka famous craft, like what is the use ingka advantages and disadvantages in comparison with products of a more modern that are circulating on the market. Lots of bias we get the advantages of the use of ingka compared with the use of modern products, for example, we can love and appreciate the products in the country in order to craftsmen such bias is still running to expand its business to be known abroad, there are also advantages such as ingka it does easily broken, the price is relatively cheap, and has a value of traditional art. Besides crafts ingka has some flaws as any product whatsoever that says the most perfect certainly has its drawbacks and as ingka discount also shortcomings in the way the physical care that is relatively difficult and complicated, ordering in large quantities may take a relatively long time because of a clash with the constraints of materials and power, for the material's still directly in the search on the tree and the seasons do not always have stock material (Patchett, 2014; Suarmawan et al., 2016). And in terms of manpower craftsmen still completely manual for the process may take longer if booking with the number of lots.

\section{Application of the use ingka}

Of the many enthusiasts as possible to craft a new ingka know this craft will ask questions first, ingka it is used for anything. This may be nature crafts ingka flexible once or commonly in use in all events, unlike modern stuff that looks just perfect for one type of event but ingka usual course is applicable in all events eg weddings, religious ceremonies and much more. And now in the public ingka have started mushrooming and demand by the people just look at a food stall or restaurant has many uses ingka to be a container or food because it is practical without having to wash once in life only need to replace the base course and ingka was used because it has elements of his art also has a unique and specific when using ingka.

\section{Purpose of use ingka}

From the development of more modern era is that craftsmen local are less competitive with modern products, certainly, all the craftsmen have a great motivation for the business as to maintain the craft ingka extinction or so craft ingka expanding to keep commonly known a lot of people and used in all activities.

\section{Conclusion}

I can conclude that ingka is an artwork done by someone who has a good idea until the results were creating a piece of art and have a sale value in the market. From this discussion, I can determine the types of existing ingka though not all because ingka it's actually the same in every region but in name only in the dressing according to their languages, so it seems there are many types ingka when only kind.

Any goods or services definitely have advantages and also disadvantages and crafts ingka also has a lot of advantages and disadvantages as advantages ingka like, have elements of art, the price is relatively cheap, can be used in all the activities and many more advantages. Besides shortage ingka as a relatively difficult treatment regimen, booking with a large amount may take a long time due to hitting the material and energy due to its complete manual. Crafts ingka created first certainly has a specific purpose for its creators and that his work can be used in all the activities for the current application ingka usually used for means a place for religious ceremonies, weddings, or that now many we meet are their application in the shop or restaurant food all over the place. Starting from that we can know that ingka it already has many fans.

From the description of the craft ingka author had many expectations precious for everyone, especially those who pursue the craft ingka that his work is always in use and always in the hearts of consumers, in addition, the goal that we love and appreciate the products local in developing ingka craft business in order to be marketed overseas.

\section{Acknowledgment}

Praise God Almighty for all his blessings so that this article can be arranged to complete on time. Do not forget I also say many thanks for the help of those who have helped and contributed to both matter and mind. And hope I hope this article can add to their knowledge and experience for the readers, For the future can improve the shape and add the contents of the article to be even better. Because of limited knowledge and experience, I'm sure there are still 
many shortcomings in this article, therefore we welcome any suggestions and constructive criticism from readers for the perfection of this article.

\section{References}

Ball, D. L. (1990). With an Eye on the Mathematical Horizon: Dilemmas of Teaching Elementary School Mathematics. Craft Paper 90-3.

Benedict, C., Brooks, S. J., Kullberg, J., Burgos, J., Kempton, M. J., Nordenskjöld, R., ... \& Johansson, L. (2012). Impaired insulin sensitivity as indexed by the HOMA score is associated with deficits in verbal fluency and temporal lobe gray matter volume in the elderly. Diabetes care, 35(3), 488-494.

Craft, C. B., Broome, S. W., Seneca, E. D., \& Showers, W. J. (1988). Estimating sources of soil organic matter in natural and transplanted estuarine marshes using stable isotopes of carbon and nitrogen. Estuarine, Coastal and Shelf Science, 26(6), 633-641.

Durant, S. M., Craft, M. E., Foley, C., Hampson, K., Lobora, A. L., Msuha, M., ... \& Pettorelli, N. (2010). Does size matter? An investigation of habitat use across a carnivore assemblage in the Serengeti, Tanzania. Journal of animal ecology, 79(5), 1012-1022.

Eichholz, G. G., Craft, T. F., \& Galli, A. N. (1967). Trace element fractionation by suspended matter in water. Geochimica et Cosmochimica Acta, 31(5), 737-745.

Esposti, R., Fastigi, M., \& Viganò, E. (2017). Italian craft beer revolution: do spatial factors matter?. Journal of Small Business and Enterprise Development, 24(3), 503-527.

Hollinshead, K. (2004). A primer in ontological craft: The creative capture of people and places through qualitative research. In Qualitative research in tourism (pp. 81-84). Routledge.

Nordmann, A. (2014). Responsible innovation, the art and craft of anticipation. Journal of Responsible Innovation, 1(1), 87-98.

O Craft, R., M Rebecca, A., Flahive, C., J Casey, W., Dueck, A., \& L Harold, K. (2011). Does size matter? Technical considerations of a regenerative tissue matrix for use in reconstructive surgery. Canadian Journal of Plastic Surgery, 19(2), 51-52.

Patchett, M. (2014). Witnessing craft: Employing video ethnography to attend to the more-than-human craft practices of taxidermy. In Video Methods (pp. 81-104). Routledge.

Suarmawan, K. A., Suharsono, N., \& Suwena, K. R. (2016). Analisis Faktor-Faktor yang Mempengaruhi Keberhasilan Usaha Mikro dan Kecil (Studi pada Usaha Kerajinan Ingka di Desa Bulian, Kec. Kubutambahan). Jurnal Pendidikan Ekonomi Undiksha, 5(1). 